\title{
Morphometry of the epidermis of an invasive megascoelecid earthworm (Amynthas gracilis, Kinberg 1867) inhabiting actively volcanic soils in the Azores archipelago
}

\author{
Luis Cunha ${ }^{\mathrm{a}, \mathrm{b}, *}$, Itxaso Campos ${ }^{\mathrm{a}}$, Rafael Montiel ${ }^{\mathrm{c}}$, Armindo Rodrigues ${ }^{\mathrm{a}, \mathrm{b}}$, Andrew J. Morgan ${ }^{\mathrm{d}}$ \\ a Public Health and Ecotoxicology Research Group (PHERG), Departmento de Biologia, Universidade dos Açores, Ponta Delgada, Portugal \\ ${ }^{\mathrm{b}}$ Centro de Investigação de Recursos Naturais (CIRN), Universidade dos Açores, Rua da Mãe de Deus, 13A - Apartado 1422, 9501-855, Ponta Delgada, Portugal

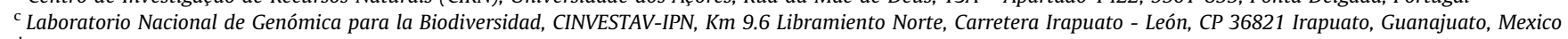 \\ ${ }^{\mathrm{d}}$ Cardiff School of Biosciences, Cardiff University, Park Place, Cardiff CF10 3US, Wales, UK
}

\section{A R T I C L E I N F O}

\section{Article history:}

Received 28 November 2009

Received in revised form

28 July 2010

Accepted 1 August 2010

Available online 24 August 2010

\section{Keywords:}

Amynthas

Earthworm

Volcanic soil

Morphometry

Epidermis

Azores

\begin{abstract}
A B S T R A C T
For the first time, the structure, dimensions, and composition of the epidermis of an invasive earthworm species that has successfully colonized hostile conditions in actively volcanic soil on São Miguel (Azores) have been measured. Metal concentrations in actively volcanic (Furnas) and volcanically inactive (Fajã) soils were similar; however, Furnas soil was characterised by elevated temperature $\left(10^{\circ} \mathrm{C}\right.$ differential), relative hypoxia, extremely high $\mathrm{CO}_{2}$ tension, and accompanying acidity. The epidermis of earthworm's resident at Fajã was approximately twice the thickness of the epidermis of conspecifics resident in Furnas soil. Reference worms transferred to Furnas soil for 14 days experienced an epidermal thinning of approximately 51\%. In comparison, when Furnas earthworms were transferred to mesocosms at the relatively benign Fajã site, their epidermal thickness increased by approximately $21 \%$ over 14 days. Earthworms resident in Furnas soil had higher goblet cell counts than the residents of volcanically inactive soil on a neighbouring island (S. Maria). Transferring worms from S. Maria to mesocosms at Furnas induced a significant increase in goblet cell counts. Clearly, the active volcanic environment at Furnas poses a multifactorial stress challenge to the epigeic $A$. gracilis colonizer.
\end{abstract}

(c) 2010 Elsevier Inc. All rights reserved.

\section{Introduction}

The high fertility of volcanic soils often attracts high-density human habitation, thus creating important risk scenarios in such regions (Hall-Spencer et al., 2008; Ribeiro et al., 2008; Viveiros et al., 2008; Viveiros et al., 2009). Geothermal biotopes are reducing environments with certain unique features, mainly characterised by elevated soil, water, and atmospheric elemental composition, together with constant diffuse degassing and high temperatures (Cruz et al., 1999; Viveiros et al., 2008; Viveiros et al., 2009). Volcanic gases typically comprise water vapour, carbon dioxide, sulphur dioxide, hydrogen sulphide, and hydrogen chloride with lesser amounts of hydrogen fluoride (Ferreira and Oskarsson, 1999). Rocks and volatiles of volcanic origin are enriched with metals/metalloids, such as $\mathrm{Al}, \mathrm{As}, \mathrm{Cu}, \mathrm{Hg}$, $\mathrm{Pb}$, and $\mathrm{Zn}$ (Cruz et al., 1999; Ferreira and Oskarsson, 1999; Aiuppa et al., 2000), with the diffusion of acidic volcanic gases

\footnotetext{
* Corresponding author at: Public Health and Ecotoxicology Research Group (PHERG), Departmento de Biologia, Universidade dos Açores, Ponta Delgada, Portugal. Fax: +351296650100.

E-mail address: luisnevescunha@gmail.com (L. Cunha).
}

through the rocks mobilising the metals in associated soils and water bodies (Cruz et al., 1999; Bagnato et al., 2007).

A primary task of ecophysiology is to understand how organisms evolve adaptations to cope with the site-specific challenges posed by stressful environments. The extant volcanic activity in certain terrestrial locations on São Miguel, one of the nine islands comprising the Azores archipelago, provide good "field-laboratories" for investigating aspects of the capacity of soil-dwelling macroinvertebrates to inhabit natural habitats continuously receiving potentially toxic chemical inputs in a milieu conducing bioavailability (Amaral et al., 2006b; Cunha et al., 2008; Rodrigues et al., 2008).

Earthworms are detritivorous macroinvertebrates conferred with the status of 'ecological engineers,' because they modify the distribution of nutrients and their availability to other organisms, whilst the biogenic structures that that they build profoundly affect soil physical properties (Jouquet et al., 2006). A number of criteria support the use of earthworms as sentinel species for soil quality assessment (Morgan and Morgan, 1998, 1999; Suthar et al., 2008) including: ecological functions; ability to inhabit extremely contaminated metalliferous soils (Morgan and Morgan, 1993); well-defined soil/tissue relationships for a number of metals (Peijnenburg, 2002); established acute and chronic toxicity tests 
(Kula and Larink, 1998); and a burgeoning body of ecotoxicogenomic protocols and observations (Spurgeon et al., 2008). Whilst the fate of inorganic contaminants in earthworm tissues is still a focus of ecotoxicological research (Cotter-Howells et al., 2005), the main thrust of the field is to assess the toxic effects of soil contaminants on the receptor organism, from the molecular-genetic and cellular levels of organisation to the physiological and demographic levels (Spurgeon et al., 2004; Bundy et al., 2008). Indeed, morphometric and complimentary cellular assays have been performed to determine the effects of volcanic soils in the Azores on the alimentary epithelia and chloragocytes of a non-resident earthworm species (Lumbricus terrestris) exposed under laboratory conditions (Amaral et al., 2006b). No comparable studies have to date been performed on indigenous species exposed in situ to volcanic soils.

The earthworm epidermis consists of supporting and basal cells, plus at least two types of mucus-secreting goblet cells with overlying cuticle (Jamieson, 1981). The integument is highly permeable, and not only serves as the sole respiratory surface, but may also be the predominant uptake route for metals such as $\mathrm{Cd}$, $\mathrm{Cu}$, and $\mathrm{Pb}$ (Vijver, Vink, Miermans and Van Gestel 2003). The structure, dimensions, and composition of epidermal surfaces have been widely used for assessing the effects of xenobiotics on molluscs (Gomot-de Vaufleury and Pihan, 2002), fish (Lamche and Burkhardt-Holm, 2000), amphibians (Fenoglio et al., 2009), and mammals (Fullerton and Hoelgaard, 1988; Iwata et al., 1999), but surprisingly in view of its anatomical features and direct interfacing with soil, not in earthworms. Thus, the main objective of the present investigation was to determine morphometrically the effect of a volcanic soil on the epidermis of a cosmopolitan endogeic earthworm species (Amynthas gracilis Kinberg, 1867; Megascolecidae) resident in the Azores by comparing populations with different exposure histories confined within mesocosms in field locations with and without volcanic activity. The amount of ecophysiological and ecotoxicological observations on this species is very limited.

\section{Materials and methods}

\subsection{Earthworm sources and exposure sites}

The Azores archipelago comprises nine islands and is located in the North Atlantic Ocean, between $36^{\circ} 45^{\prime}-39^{\circ} 43^{\prime} \mathrm{N}$ and $24^{\circ} 45^{\prime}-31^{\circ} 17^{\prime} \mathrm{W}$, at the triple junction of Eurasian, African, and North American plates, characterised by a complex tectonic settlement, where seismic and volcanic phenomena are common (Booth et al., 1978). São Miguel and Santa Maria are the two most eastern islands of the archipelago, and the latter is the oldest of all nine. São Miguel is the largest island $\left(757 \mathrm{~km}^{2}\right)$, which presents several active volcanic spots, including fumarolic fields, cold, and thermal springs and soil diffuse degassing (Viveiros et al., 2008). Santa Maria $\left(92 \mathrm{~km}^{2}\right)$ is also of volcanic origin, but no volcanic activity has occurred there for $>3$ million years (Feraud et al., 1981). Two field sites on São Miguel, differing in their contemporary volcanic activity (thermal and degassing outputs), were selected for microcosm exposures: (a) Furnas, which displays the most conspicuous degassing and geothermal activity in the entire Azores archipelago and (b) Fajã, which does not presently display any thermal and degassing phenomena (Table 1).

A group of adult (clitellate) A. gracilis from Furnas, $37^{\circ} 46^{\prime} 24.6^{\prime \prime} \mathrm{N} 25^{\circ} 18^{\prime} 10.3^{\prime \prime} \mathrm{W}$ (São Miguel) and another group from Ribeira $36^{\circ} 57^{\prime} 04.6^{\prime \prime} \mathrm{N} 25^{\circ} 05^{\prime} 38.9^{\prime \prime} \mathrm{W}$ (Santa Maria) were collected by digging and hand-sorting during Spring 2008, and were assigned to factorial-design treatments (with earthworm source and exposure site as factors, and exposure time as a covariable) within $24 \mathrm{~h}$ of collection (Fig. 1). Twelve individual worms were placed in perforated, cube-shaped, plastic boxes (volume $20 \mathrm{~L}$ ) covered with a permeable mesh. Ten boxes were used per site, with five boxes per 'treatment' (Furnas- or S. Maria-derived worms). Soil from the given exposure site was used to which approximately $120 \mathrm{~g}$ of re-wetted, oven-dried (at $140{ }^{\circ} \mathrm{C}$ ), urine-free horse manure (produced from a single known horse not subject to any medication) was deposited on the soil surface at the beginning and after 14 days exposure. For $t_{0}$ analysis, five earthworms from $S$. Maria and five from the two Furnas (S. Miguel) populations were randomly chosen.

In the Furnas (volcanically active site) exposures, five individuals (one from each of the appropriate replicated box) from both original sources (i.e. Furnas and S. Maria) were randomly sampled for analysis at 4,8 , and 14 days. Sampling at the Furnas site on day 28 was not possible due to the fact that at some indeterminate time between scheduled sampling days 14 and 28, the microcosm boxes were vandalized and most earthworms escaped. In the Fajã $37^{\circ} 45^{\prime} 12.2 \mathrm{~N} 25^{\circ} 38^{\prime} 21.3^{\prime \prime} \mathrm{W}$ (S. Miguel, volcanically inactive site) exposures, five earthworms from both of the original populations (Furnas and S. Maria) were randomly sampled for analysis at $4,8,14$, and 28 days.

Fig. 1 provides a schematic representation of the experimental design. After sampling, the earthworms were immediately transferred to the laboratory, where they were depurated of gut contents by placing them on moistened paper for $36 \mathrm{~h}$ A fresh piece of tissue located 3-4 segments posterior to clitellum was excised from each individual earthworm for use in light microscopy and morphometry, the rest of the earthworm body was used for metal analysis.

\subsection{Metal analyses}

The soft tissues of A. gracilis were dried $\left(130^{\circ} \mathrm{C}\right)$ for $48 \mathrm{~h}$, digested in aqua regia at $95{ }^{\circ} \mathrm{C}$ for $2 \mathrm{~h}$, and then microwave-digested inside closed vessels for $2 \mathrm{~min}$. Digests were diluted and analysed for $\mathrm{Ca}, \mathrm{Cu}, \mathrm{K}, \mathrm{Pb}$, and $\mathrm{Zn}$ on a Finnegan Mat Element 2 High Resolution ICP/MS (Actlabs, Canada). Soil samples at $10 \mathrm{~cm}$ were thoroughly homogenised, air-dried, and gently crushed prior to aqua regia digestion and ICP/MS metal analyses as for worm tissues. A quality control was implemented that included reagent blanks and reference materials. The accuracy, was always higher than $95 \%$ for the analysed elements, and was assessed through the analysis of eight standard reference materials GXR-1, GXR-2, GXR-4, GXR-6, OREAS-13 P, SDC-1, SCO-1, NIST694, and DNC-1 (Actlabs, Canada). Ultrapure water was used to prepare blanks and calibration standards.

\subsection{Histological processing}

Each fresh piece of tissue was fixed in neutral-buffered formaldehyde for $5 \mathrm{~h}$, dehydrated in graded ethanol series, and embedded in paraffin wax. Histological section ( $4 \mu \mathrm{m}$ thickness) were cut on a Leitz 1512 microtome (Leica Microsystems,

Table 1

Physical properties and concentrations of metals ( $\mu \mathrm{g} \mathrm{g}^{-1}$ dry weight) in soils of Furnas, Fajã (São Miguel) and Ribeira (Santa Maria). Source of data of the soils from Ribeira site: (Amaral et al., 2006b).

\begin{tabular}{|c|c|c|c|c|c|c|c|c|c|}
\hline Site & Soil $\mathrm{CO}_{2}$ (vol\% ) & Soil $\mathrm{O}_{2}$ (vol\%) & $\mathrm{CO}(\mathrm{ppm})$ & Soil temperature $\left({ }^{\circ} \mathrm{C}\right)$ & Surface temperature $\left({ }^{\circ} \mathrm{C}\right)$ & Moisture (\%) & $\mathrm{pH}\left(\mathrm{H}_{2} \mathrm{O}\right)$ & Clay-silt (\%) & OM (\%) \\
\hline \multicolumn{10}{|c|}{ Physical properties } \\
\hline \multicolumn{10}{|c|}{ São Miguel } \\
\hline Furnas & 54.45 & 9.7 & 0.5 & 37 & 17 & 25 & 5.8 & 76 & 3.4 \\
\hline Faja & 0 & 21.1 & 0 & 18 & 18 & 34 & 7.8 & 75 & 3.4 \\
\hline \multicolumn{10}{|c|}{ Santa Maria } \\
\hline Ribeira & - & - & - & - & - & 17.72 & 6.9 & 80 & 2 \\
\hline \multicolumn{10}{|c|}{ Metal content } \\
\hline & & & $\mathrm{Cu}$ & $\mathrm{Pb}$ & $\mathrm{Zn}$ & K & $\mathrm{Ca}$ & & \\
\hline \multicolumn{10}{|c|}{ São Miguel } \\
\hline Furnas & & & 42 & 81 & 225 & 32,909 & 9149 & & \\
\hline Faja & & & 41 & 90 & 195 & 21,261 & 22,516 & & \\
\hline \multicolumn{10}{|c|}{ Santa Maria } \\
\hline Ribeira* & & & 66 & 74 & 197 & 83,700 & 14,600 & & \\
\hline
\end{tabular}




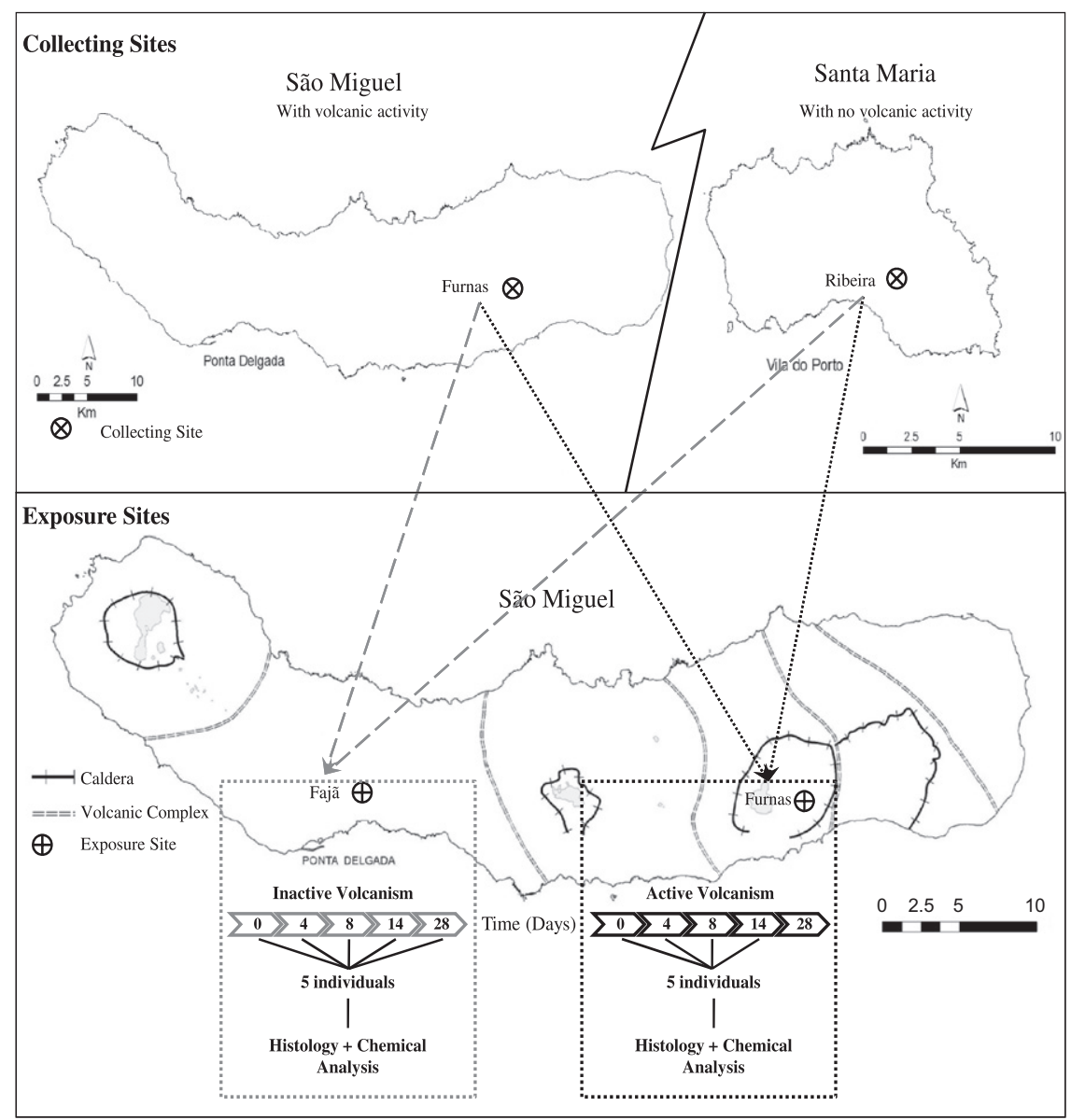

Fig. 1. Schematic representation of the experimental design.

Wetzlar, Germany), mounted on albumin-coated slides (Menzel-Glaser, Braunscheig, Germany), dried at $40{ }^{\circ} \mathrm{C}$ for $24 \mathrm{~h}$, and stored at room temperature until staining.

\subsection{Morphometry}

Sections were stained with haematoxylin-eosin (Martoja and Martoja-Pierson, 1970). Epidermis thickness was measured in four sections (four fields per section), $28 \mu \mathrm{m}$ apart, in each individual worm. Images were captured using a CoolSNAP-cf camera (Photometrics GmbH, Munich) coupled to a light microscope, and analysed with Image Pro-Plus 5.0 software (Media Cybernetics, Silver Springs). Thus, for statistical analysis the average value from 16 measurements per individual earthworm was considered the true replicate ( $n=5$ per treatment).

\subsection{Goblet cell counts}

Another set of sections was stained with PAS-Alcian Blue (pH 2.5) to distinguish neutral and acidic mucopolysaccharides (Martoja and Martoja-Pierson, 1970), so that the blue-stained goblet cells containing acid mucins could be located. Counts were made in four microscope fields on two different sections $45 \mu \mathrm{m}$ apart. Goblet cell numbers were expressed both as cells $\mu \mathrm{m}^{-1}$ and cells $\mu \mathrm{m}^{-2}$ (by dividing the cells $\mu \mathrm{m}^{-1}$ by the cross-sectional area of the epidermis).

\subsection{Statistical analyses}

Epidermal thickness measurements and goblet cell counts, respectively, were analysed (with or without $\log _{e}$ transformation, as appropriate) by two-way ANOVA (using earthworm source and exposure site as factors, and exposure time as a covariable) and Tukey post hoc pair-wise comparisons, with $p \leq 0.05$ considered the level of significance.

\section{Results}

\subsection{Soil and earthworm metal analyses}

Although the measuring accuracy of the chemical analysis was always higher than $95 \%$, the number of replicates per day was not enough to do a robust statistical comparison. Therefore the values presented should be considered with merely descriptive value and should be interpreted accordingly.

$\mathrm{Cu}, \mathrm{Pb}$, and $\mathrm{Zn}$ concentrations were very similar in the soils from the volcanically active (Furnas) and inactive (Fajã) sites (Table 1). However, Ca concentration appeared to be appreciably higher and $\mathrm{K}$ concentration was appreciably lower in Furnas soil. Other noteworthy differences between the two soils are the lower $\mathrm{pH}$ (5.8 compared with 7.8), and exceptionally high $\mathrm{CO}_{2}$ content (with accompanying lower $\mathrm{O}_{2}$ and higher $\mathrm{CO}$ content), in Furnas soil (Table 1). The Ribeira (S. Maria), site from which 'reference' worms were derived, had similar metal composition (apart from much higher $\mathrm{K}$ concentration) to Furnas and Fajã soils, and a neutral $\mathrm{pH}$ (Table 1$)$.

$\mathrm{Cu}, \mathrm{Pb}$, and $\mathrm{Zn}$ concentrations were higher in earthworms maintained for a comparable exposure period of 14 days within mesocosms containing actively volcanic Furnas soil compared with an inactive Fajã soil, irrespective of the source of the earthworms (Fig. 2) and despite the similarities of the metal contents of the soils at the exposure sites (Table 1). In fact, $\mathrm{Cu}, \mathrm{Pb}$, and $\mathrm{Zn}$ showed an accumulation pattern in both populations exposed to Furnas environment, with the highest concentration values found at 14 days of exposure when compared with $t_{0}$, 


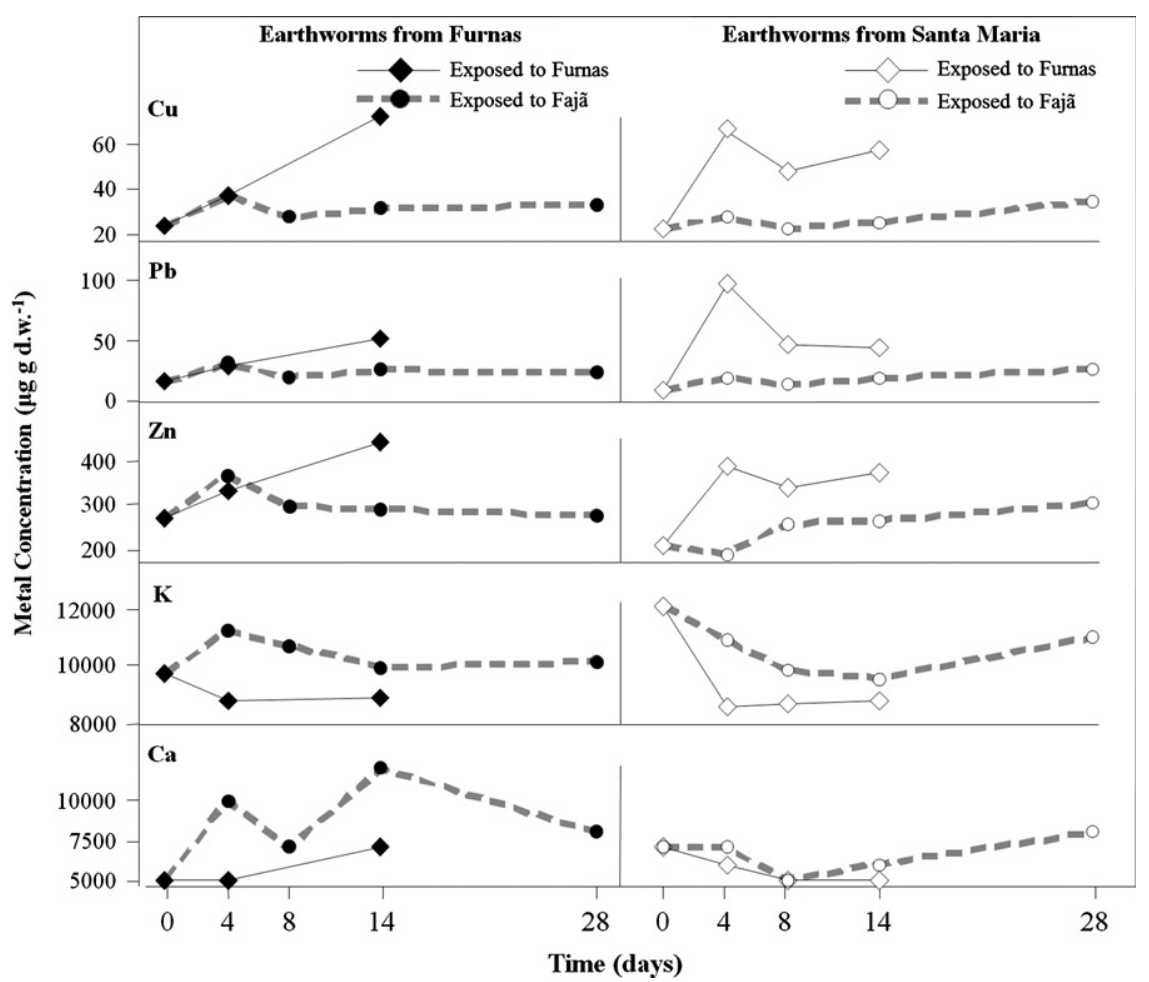

Fig. 2. Concentrations of metals ( $\mu$ g element $g$ of dry weight ${ }^{-1}$ ) measured by HR-ICP/MS in tissues of Amynthas gracilis collected in Furnas, S. Miguel and S. Maria islands which were exposed to, Furnas a site with volcanic activity and other with no volcanic activity, Fajã.
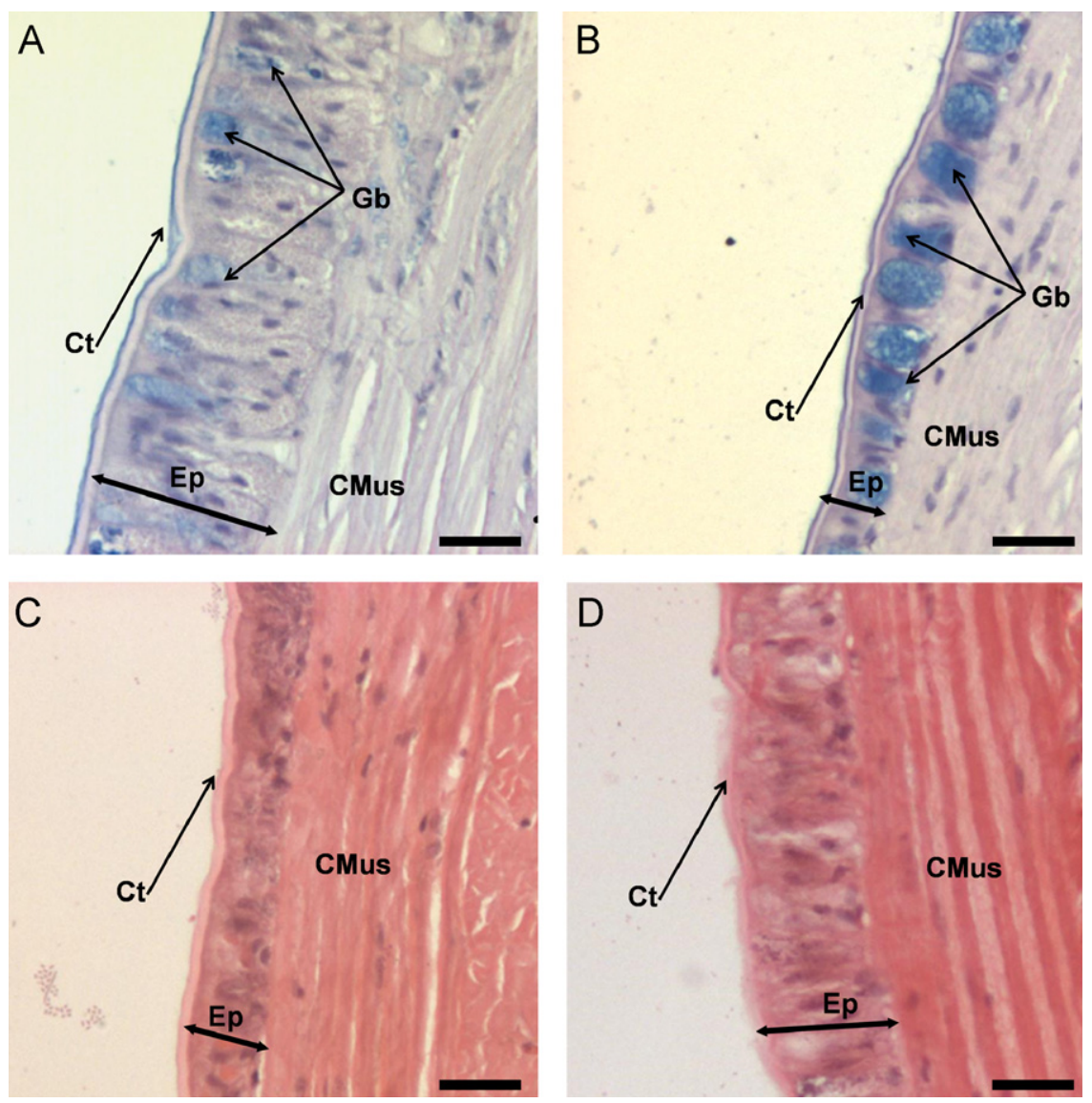

Fig. 3. Micrographs of epidermal epithelia of Amynthas gracilis from Ribeira, Santa Maria before exposure (A) and after exposure (B) in Furnas and Furnas earthworms before exposure (C) and after exposure (D) to the non-volcanic Fajã Soil. Scale bars $=25 \mu \mathrm{m}$. Ct, cuticle;Gb, Goblet cells; Ep, epidermis; CMus, circular muscle; LgMus, longitudinal muscle. 
revealing differences in the bioavailability of metals. Tissue $\mathrm{K}$ concentrations did not differ significantly amongst the earthworm 'treatment' groups; however, Ca concentrations tended to be lower in earthworms maintained in the relatively Ca-impoverished, acidic, Furnas soil compared with their counterparts maintained on Fajã soil (Fig. 2).

\subsection{Epidermal structure}

\subsubsection{Epidermal thickness}

The epidermis of earthworm's resident at the reference site (Ribeira) on S. Maria was approximately twice the thickness of the epidermis of conspecifics resident in volcanically active Furnas soil (Fig. 3). When the reference earthworms were transferred to mesocosms at the volcanically inactive Fajã soil, the epidermal thickness decreased by approximately $30 \%$ over a 14 day exposure period. In comparison, S. Maria worms transferred to Furnas soil for 14 days experienced an epidermal thinning of approximately 51\% (Fig. 4). Earthworms resident at Furnas experienced a modest epidermal thickening (approximately 21\%) after 14 day maintenance in Fajã soil, but a progressive thinning of the epidermis (approximately 24\%) when confined within mesocosms of their 'own' soil (Fig. 4).

Correlation analysis between earthworm tissue heavy metal concentrations and epidermis thickness (Table 2) indicated significant negative relationships in the cases of Furnas and S. Maria worms maintained on Furnas soil. There were no observable significant correlations between heavy metal burden and the morphometric parameter in either earthworm population transferred to mesocosms containing Fajã soil.

\subsubsection{Goblet cell counts}

The epidermis of earthworms resident in Furnas soil had significantly higher goblet cell counts (expressed as number per unit epidermis area) than the residents in volcanically inactive S. Maria soil (Fig. 5). Transferring worms from both populations to mesocosms of an inactive Fajã soil (14 and 28 days) or active Furnas soil (14 days) tended to induce an increase in goblet cell counts. The two modes of expressing the cell counts gave some inconsistencies. It is our view that expressing cells per unit epidermal area (cf. Fig. 5C and D) rather than per linear dimension yielded more easily interpretable observations (cf. Fig. 5A and B); if true, then it is evident that transferring worms to mesocosms of Furnas soil induced goblet cell accretion more strongly than transfers to Fajã soil for the same exposure period. Certainly, Furnas and (particularly) S. Maria worms enclosed in Furnas soil for 14 days had significantly elevated goblet cell counts.

\section{Discussion}

\subsection{Chemical analysis}

Most of the analysed elements showed similar concentrations in both experimental soils; however, inoculated earthworm showed temporal differences in accumulated tissue metal

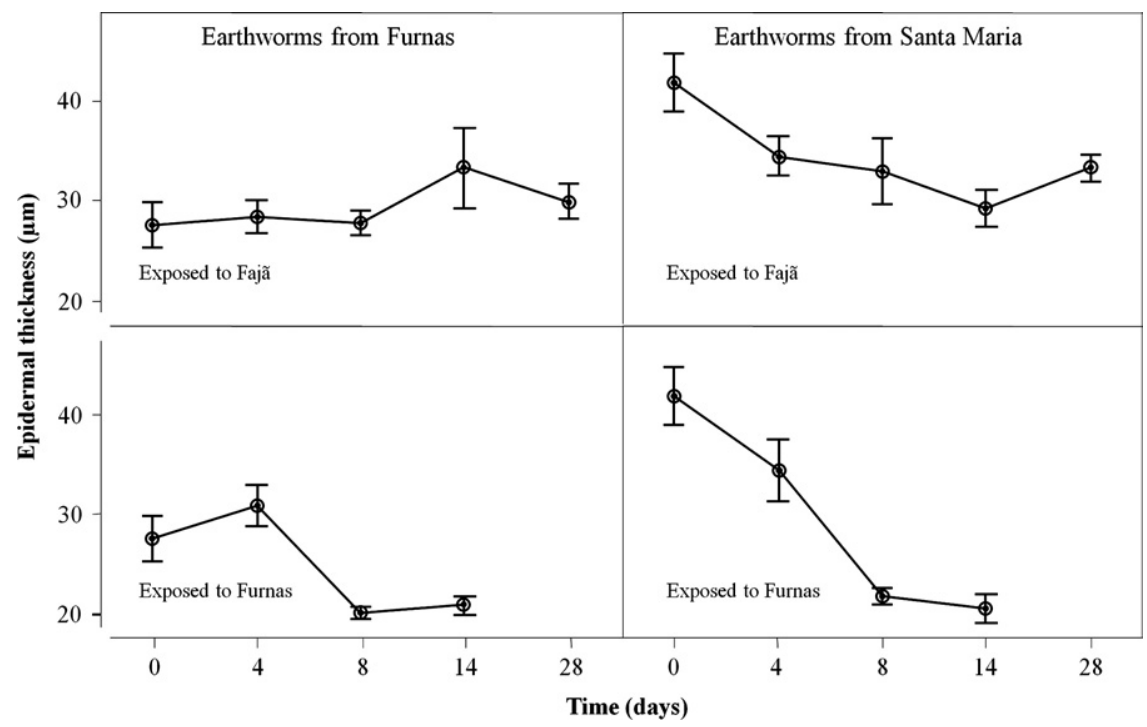

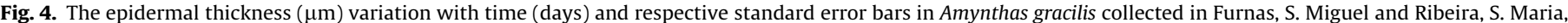
which were exposed to the active volcanic environment (Furnas) and to place without volcanic activity (Fajã).

Table 2

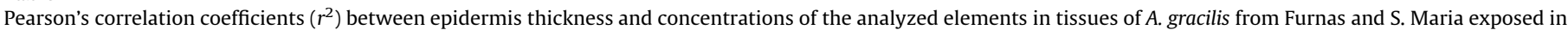
microcosms to the active volcanism of Furnas during 14 days and to a site without volcanic activity, Fajã during 28 days.

\begin{tabular}{|c|c|c|c|c|}
\hline \multirow[b]{2}{*}{ Elements } & \multirow{2}{*}{$\begin{array}{l}\text { Earthworms from Furnas, Sâo Miguel } \\
\text { Furnas-active volcanism }\end{array}$} & \multicolumn{3}{|c|}{ Earthworms from Ribeira, Santa Maria } \\
\hline & & Fajã-inactive volcanism & Furnas-active volcanism & Fajã-inactive volcanism \\
\hline $\mathrm{Cu}$ & $-0.614^{*}$ & 0.125 & $-0.432^{*}$ & -0.095 \\
\hline $\mathrm{Pb}$ & $-0.585^{*}$ & 0.144 & -0.166 & -0.241 \\
\hline $\mathrm{Zn}$ & $-0.575^{*}$ & -0.067 & $-0.522 *$ & -0.187 \\
\hline Total heavy Metal load & $-0.738^{*}$ & 0.268 & $0.678^{*}$ & 0.279 \\
\hline
\end{tabular}

* Significant correlations at $p \leq 0.05$. 

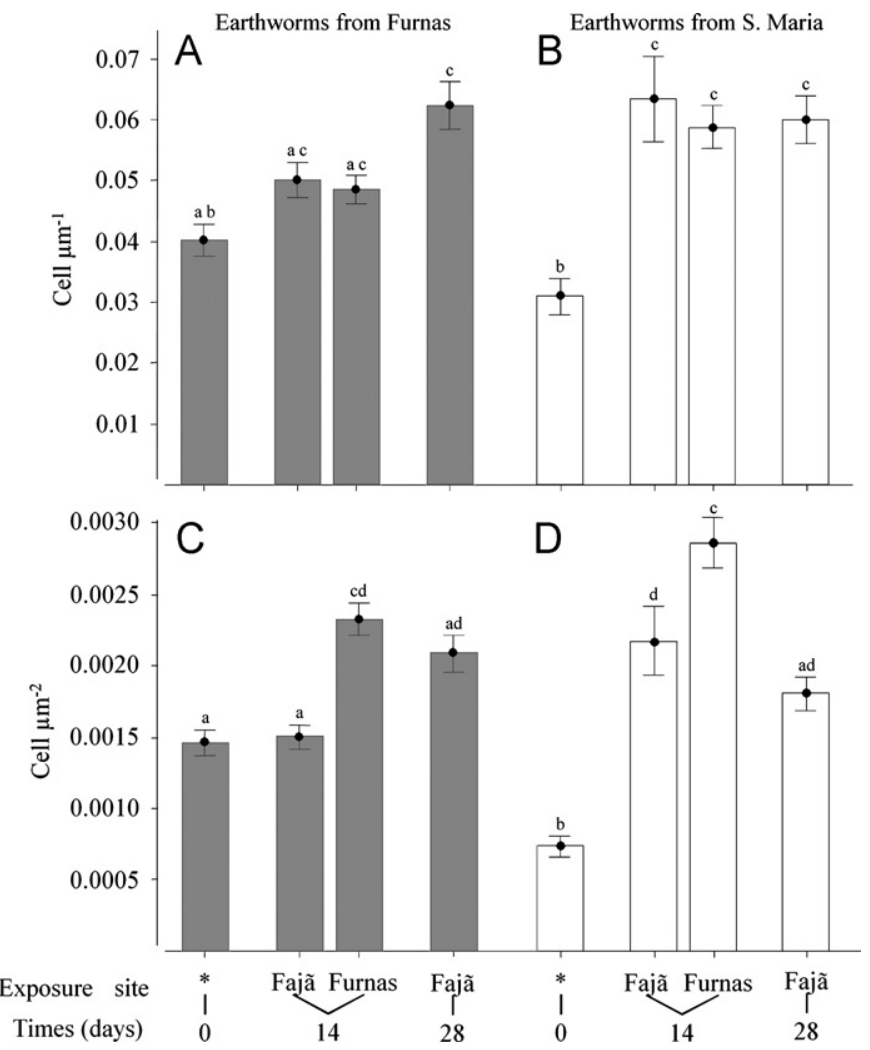

Fig. 5. A and B, Goblet cells numbers per epidermis length (Cell $\mu \mathrm{m}^{-1}$ ) and $C$ an $D$ per epidermis cross-sectional area $\left(\right.$ Cell $\mu \mathrm{m}^{-2}$ ) in Amynthas gracilis collected in Furnas, S. Miguel and Ribeira, S. Maria which were exposed to Furnas, a volcanic environment and to place without volcanic activity, Fajã. Different letters above and below bars mean significant differences at $p \leq 0.05$

concentrations. It has been recorded previously that the high mineralisation and trace element bioavailability in Furnas soils and water together, together with diffuse degassing phenomena, do influence the tissue accumulation of metals by representatives of the local fauna (Cruz et al., 1999; Cunha et al., 2008; Rodrigues et al., 2008; Viveiros et al., 2009). Tissue metal concentrations (especially $\mathrm{Zn}$ and $\mathrm{Cu}$ ) in earthworms at the end of the experimental exposure to Furnas soil were found to be almost two-fold higher than the soil concentrations, and even similar to what was found in earthworms living in, or inoculated into, polluted sites (Ruiz et al., 2009). Moreover it is widely known that soil physical parameters, such as $\mathrm{pH}$, organic matter content, and \% clay-silt, can exert modulating influences on metal bioavailability (Peijnenburg, 2002). According to Amaral et al. (2006a, b) the physico-chemical characteristics of Furnas soil promote the mobility and the bioavailability of metals such as $\mathrm{Zn}$. For instance, the relatively low soil $\mathrm{pH}$ arising from the continuous ingress of $\mathrm{CO}_{2}$ increases the bioavailability of $\mathrm{Cu}, \mathrm{Pb}$, and $\mathrm{Zn}$ due to reduced sorption of these divalent cations onto oxides of Fe and Mn.

Although, the role of temperature on metal bioaccumulation is not fully understood, it is evident that temperature increase within the thermal tolerance ranges of plants and animals tend to promote metal bioaccumulation (Khan et al., 2007; Mubiana and Blust, 2007; Chen et al., 2008). In the context of the present study, it is germane to note that temperature significantly modulates the toxicity of chemicals (Spurgeon et al., 1997). Whilst hypoxia and potential hypercapnia independently can exert stressful cytological effects, it is clear that the acidic soil matrix and elevated temperature featured at the actively volcanic Furnas site jointly increase metal mobility.

\subsection{Morphometry and cell composition}

Conspicuous volcanic stress factors, such as temperature, hypoxia, $\mathrm{pH}$, and heavy metal presence, are known to cause changes in the phasic activity, atrophy, and cellular composition of several animal tissues (Amaral et al., 2006b; Andersen et al., 2006; Hourdez and Lallier, 2007; Cunha et al., 2008). Such structural changes can be assessed morphometrically, a technique that is sufficiently sensitive to detect epithelial thinning due to environmental stress in the digestive epithelia and reproductive tissues of several invertebrates (Vega et al., 1989; Marigomez et al., 1998; Siekierska and Urbanska-Jasik, 2002). Morphological alterations are not uncommon among organisms exposed to extreme environments. A clear example is the case of the hydrothermal tubeworm (Ridgeia piscesae) which shows a 'short-fat' morphotype that lives in a microhabitat of high temperature but low $\mathrm{O}_{2}$ concentration, whilst the 'long-skinny' morphotype of the same species lives in a cooler, more $\mathrm{O}_{2}$-rich, microhabitat (Andersen et al., 2006). It is noteworthy that the branchial surface area (i.e. essentially the respiratory gas exchange surface) is similar in both morphotypes, but the branchial thickness, thus the diffusion distance, is lower in the 'short-fat' compared with the 'long-skinny' worms (Andersen et al., 2006; Hourdez and Lallier, 2007). Cytological alterations induced by heavy metal exposures have been observed in different types of epithelial tissues in several invertebrate taxa (Zaldibar et al., 2007; Cunha et al., 2008), and vertebrates (Pandey et al., 2008; Srivastava et al., 2009). However, the metal concentrations in the actively volcanic soil at Furnas are not particularly excessive, especially in comparison with those often encountered in mine-associated soils (Corp and Morgan, 1991), and lead to the conclusion that cations alone, even under the relatively acidic prevailing conditions, may not be the primary cause of the epidermal perturbations observed in the resident earthworms.

In the earthworm A. gracilis inhabiting volcanic soils, it is plausible to consider epidermal thinning as a physiological adaptation (probably plastic rather than constitutive) for reducing the $\mathrm{O}_{2}$ diffusion distance across its dermal respiratory surface. By such a structural modification, the earthworm can obtain the $\mathrm{O}_{2}$ that it requires for metabolism from its hypoxic native (actively volcanic) Furnas soil. The high soil temperature at Furnas also presumably increases metabolic $\mathrm{O}_{2}$ consumption and demand, adding a premium to improved trans-epidermal diffusion efficiency. The structural change in the gas permeable exchange surface of Amynthas seems to be functionally analogous to the thinning of alveolar epithelia observed in $\mathrm{CO}_{2}$-exposed neonatal mice compared with controls (Li et al., 2006).

The epidermis tissue interface is known to act as the primary barrier protecting earthworms from potential bacterial infections (Fischer and Horváth, 1977). Since the epidermis also plays functional roles in an ion transport, it is unsurprising that nonessential metal ions and xenobiotics enter the organism through it (Dietz, 1974; Clauss, 2001). It is noteworthy that there is an evidence that the dermal route is the predominant route for metal uptake by earthworms (Vijver et al., 2003). Reducing epidermal thickness and increasing body surface humidity by goblet cells secretion confers respiratory advantages, but could increase exposure to metals, particularly in acidic environments such as pertain at Furnas. To counter this, the worms may upregulate continuous mucus production for cation trapping and shedding; to this extent, increasing goblet cell counts would be beneficial. This notion is consistent with the observations that secreted mucopolysaccharides on the dermal surface trap heavy metals (Fischer and Horváth, 1977; Back, 1990), whilst the amount of surface-adsorbed $\mathrm{Cd}$ and $\mathrm{Zn}$ at any given time is minimal 
compared with the amount of internally sequestered metal (Vijver et al., 2005). The progressive thinning of the epidermis in Furnas's earthworms when confined within mesocosms of their 'own' environment could be attributable to the seemingly inevitable, but poorly understood, changes in the physicochemical properties of the soils, when they were inserted into the mesocosms. For example, the phenomenon of further increases in accumulated metal concentrations in earthworms inhabiting metalliferous field soils when maintained on their 'own' soils in the laboratory has been observed by Corp and Morgan (1991). In any case, the limited volume of the mesocosms deployed in the present study may have amplified the effects of metals and other edaphic stressors on epidermis morphology by restricting the normal range of eco-physiological activities in the confined worms.

\section{Conclusion}

In conclusion, the active volcanic environment at Furnas poses a multifactorial stress challenge to the local soil-dwelling organisms, including the earthworm $A$. gracilis. In normal circumstances, it would be deemed imperative to attempt to dissect the effects of the individual chemical and physical stressors by performing robust, controlled, laboratory exposures, and monitoring the induced changes with a suite of morphological, physiological, and molecular observations. However, active volcanic soils comprise a suite of dynamic and, in some cases, volatile constituents that are more-or-less continuously expelled. To this extent, such sites are terrestrial equivalents of marine hydrothermal vents, and cannot easily be replicated in the laboratory. The recommendation from the 3rd Workshop on Earthworm Ecotoxicology that "more attention should be given to field testing in general" and "there is a need to explore the baseline variables influencing biomarker responses (confounding factors such as drought, temperature) and the linkage between biomarker and physiological responses" (Van Gestel and Weeks, 2004) is particularly opposite for active volcanic soils.

\section{Acknowledgments}

We would like to thank to Fatima Viveiros and Catarina Silva for the help given in the characterisation of the exposure sites and José Talavera for the taxonomical identification of the studied specimens. This study was financially supported by CIRN (University of the Azores), and DRCT (Government of the Azores). Luis Cunha was supported by a Doctoral grant from DRCT (M312/F/029/2007).

\section{References}

Aiuppa, A., Allard, P., D’Alessandro, W., Michel, A., Parello, F., Treuil, M., Valenza, M., 2000. Mobility and fluxes of major, minor and trace metals during basalt weathering and groundwater transport at Mt. Etna volcano (Sicily). Geochim. Cosmochim. Acta 64, 1827-1841.

Amaral, A., Cruz, J., Cunha, R., Rodrigues, A., 2006a. Baseline levels of trace metals in volcanic soils of the Azores (Portugal). Soil Sediment Contam. 15, 123-130.

Amaral, A., Soto, M., Cunha, R., Marigómez, I., Rodrigues, A., 2006b. Bioavailability and cellular effects of metals on Lumbricus terrestris inhabiting volcanic soils. Environ. Pollut. 142, 103-108.

Andersen, A., Flores, J., Hourdez, S., 2006. Comparative branchial plume biometry between two extreme ecotypes of the hydrothermal vent tubeworm Ridgeia piscesae. Can. J. Zool. 84, 1810-1822.

Back, H., 1990. Epidermal uptake of $\mathrm{Pb}, \mathrm{Cd}$, and $\mathrm{Zn}$ in tubificid worms. Oecologia 85, 226-232.

Bagnato, E., Aiuppa, A., Parello, F., Calabrese, S., D’Alessandro, W., Mather, T. McGonigle, A., Pyle, D., Wängberg, I., 2007. Degassing of gaseous (elementa and reactive) and particulate mercury from Mount Etna volcano (Southern Italy). Atmos. Environ. 41, 7377-7388.
Booth, B., Croasdale, R., Walker, G., 1978. A quantitative study of five thousand years of volcanism on Sao Miguel, Azores. Philos. Trans. R. Soc. London, A, 271-319.

Bundy, J., Sidhu, J., Rana, F., Spurgeon, D., Svendsen, C., Wren, J., Stürzenbaum, S., Morgan, A., Kille, P., 2008. 'Systems toxicology' approach identifies coordinated metabolic responses to copper in a terrestrial non-model invertebrate, the earthworm Lumbricus rubellus. BMC Biol. 6, 25.

Chen, Y., Wang, C., Wang, G., Luo, C., Mao, Y., Shen, Z., Li, X., 2008. Heating treatment schemes for enhancing chelant-assisted phytoextraction of heavy metals from contaminated soils. Environ. Toxicol. Chem. 27, 888-896.

Clauss, W., 2001. Epithelial transport and osmoregulation in annelids. Can. J. Zool. 79, 192-203.

Corp, C., Morgan, A.J., 1991. Accumulation of heavy metals from polluted soils by the earthworm, Lumbricus rubellus: can laboratory exposure of 'control' worms reduce biomonitoring problems? Environ. Pollut. 74 39-52.

Cotter-Howells, J., Charnock, J., Winters, C., Kille, P., Fry, J., Morgan, A., 2005. Metal compartmentation and speciation in a soil sentinel: the earthworm, Dendrodrilus rubidus. Environ. Sci. Technol. 39, 7731-7740.

Cruz, J., Coutinho, R., Carvalho, M., Oskarsson, N., Gislason, S., 1999. Chemistry of waters from Furnas volcano, Sao Miguel, Azores: fluxes of volcanic carbon dioxide and leached material. J. Volcanol. Geotherm. Res. 92, 151-167.

Cunha, L., Amaral, A., Medeiros, V., Martins, G., Wallenstein, F., Couto, R., Neto, A., Rodrigues, A., 2008. Bioavailable metals and cellular effects in the digestive gland of marine limpets living close to shallow water hydrothermal vents. Chemosphere 71, 1356-1362.

Dietz, T., 1974. Active chloride transport across the skin of the earthworm, Lumbricus terrestris L. Comp. Biochem. Physiol. A. 49, 251-258.

Fenoglio, C., Grosso, A., Boncompagni, E., Gandini, C., Milanesi, G., Barni, S., 2009. Exposure to heptachlor: evaluation of the effects on the larval and adult epidermis of Rana kl. esculenta. Aquat. Toxicol. 91, 151-160.

Feraud, G., Gastaud, J., Schmincke, H., Pritchard, G., Lietz, J., Bleil, U., 1981. New KAr ages, chemical analyses and magnetic data of rocks from the islands of Santa Maria (Azores), Porto Santo and Madeira (Madeira Archipelago) and Gran Canaria (Canary Islands). Bull. Volcanol. 44, 359-375.

Ferreira, T., Oskarsson, N., 1999. Chemistry and isotopic composition of fumarole discharges of Furnas caldera. J. Volcanol. Geotherm. Res. 92, 169-179.

Fischer, E., Horváth, I., 1977. Cytochemical studies on the cuticle and epidermis of Tubifex tubifex Müll. with special regard to the localization of polysaccharides, heavy metals and the DAB-reactivity. Histochem. Cell Biol. 54, 259-271.

Fullerton, A., Hoelgaard, A., 1988. Binding of nickel to human epidermis in vitro. Br. J. Dermatol. 119, 675-682.

Gomot-de Vaufleury, A., Pihan, F., 2002. Methods for toxicity assessment of contaminated soil by oral or dermal uptake in land snails: metal bioavailability and bioaccumulation. Environ. Toxicol. Chem. 21, 820-827.

Hall-Spencer, J., Rodolfo-Metalpa, R., Martin, S., Ransome, E., Fine, M., Turner, S., Rowley, S., Tedesco, D., Buia, M., 2008. Volcanic carbon dioxide vents show ecosystem effects of ocean acidification. Nature 454, 46-47.

Hourdez, S., Lallier, F., 2007. Adaptations to hypoxia in hydrothermal-vent and cold-seep invertebrates. Rev. Environ. Sci. Biotechnol. 6, 143-159.

Iwata, M., Takebayashi, T., Ohta, H., Alcalde, R., Itano, Y., Matsumura, T., 1999. Zinc accumulation and metallothionein gene expression in the proliferating epidermis during wound healing in mouse skin. Histochem. Cell Biol. 112, 283-290.

Jamieson, B., 1981. The Ultrastructure of the Oligochaeta. Academic Press, London.

Jouquet, P., Dauber, J., Lagerlöf, J., Lavelle, P., Lepage, M., 2006. Soil invertebrates as ecosystem engineers: intended and accidental effects on soil and feedback loops. Appl. Soil Ecol. 32, 153-164.

Khan, M., Ahmed, S., Salazar, A., Gurumendi, J., Khan, A., Vargas, M., von Catalin, B. 2007. Effect of temperature on heavy metal toxicity to earthworm Lumbricus terrestris (Annelida: Oligochaeta). Environ. Toxicol., 22.

Kula, H., Larink, O., 1998. Tests on the earthworms Eisenia fetida and Aporrectodea caliginosa. In: Gestel, H.L.C.A.M.V. (Ed.), Handbook of Soil Invertebrate Toxicity Tests. Wiley, New York 95-111

Lamche, G., Burkhardt-Holm, P., 2000. Changes in apoptotic rate and cell viability in three fish epidermis cultures after exposure to nonylphenol and to a wastewater sample containing low concentrations of nonylphenol. Biomarkers 5, 205-218.

Li, G., Zhou, D., Vicencio, A.G., Ryu, J., Xue, J., Kanaan, A., Gavrialov, O., Haddad, G.G., 2006. Effect of carbon dioxide on neonatal mouse lung: a genomic approach. J. Appl. Physiol. 101, 1556-1564.

Marigomez, I. Kortabitarte, M. Dussart, G, 1998. Tissue-level biomarkers in sentinel slugs as cost-effective tools to assess metal pollution in soils. Arch. Environ. Contam. Toxicol. 34, 167-176.

Martoja, R., Martoja-Pierson, M., 1970. Técnicas de Histología Animal. TorayMasson, Barcelona.

Morgan, J.E., Morgan, A.J., 1993. Seasonal changes in the tissue-metal (Cd, Zn and $\mathrm{Pb})$ concentrations in two ecophysiologically dissimilar earthworm species: pollution-monitoring implications. Environ. Pollut. 82, 1-7.

Morgan, J., Morgan, A., 1998. The distribution and intracellular compartmentation of metals in the endogeic earthworm Aporrectodea caliginosa sampled from an unpolluted and a metal-contaminated site. Environ. Pollut. 99, 167-175.

Morgan, J., Morgan, A., 1999. The accumulation of metals (Cd, Cu, Pb, Zn and Ca) by two ecologically contrasting earthworm species (Lumbricus rubellus and Aporrectodea caliginosa): implications for ecotoxicological testing. Appl. Soil Ecol. 13, 9-20. 
Mubiana, V., Blust, R., 2007. Effects of temperature on scope for growth and accumulation of $\mathrm{Cd}, \mathrm{Co}, \mathrm{Cu}$ and $\mathrm{Pb}$ by the marine bivalve Mytilus edulis. Mar. Environ. Res. 63, 219-235.

Pandey, S., Parvez, S., Ansari, R., Ali, M., Kaur, M., Hayat, F., Ahmad, F., Raisuddin, S., 2008. Effects of exposure to multiple trace metals on biochemical, histological and ultrastructural features of gills of a freshwater fish Channa punctata Bloch. Chem.-Biol. Interact. 174, 183-192.

Peijnenburg, W., 2002. Bioavailability of metals to soil invertebrates. In: Allen, H.E. (Ed.), Bioavailability of Metals in Terrestrial Ecosystems: importance of Partitioning for Bioavailability to Invertebrates, Microbes, and Plants. SETAC, Pensacola, Florida 89-112.

Ribeiro, D.C., Martins, G., Nogueira, R., Cruz, J.V., Brito, A.G., 2008. Phosphorus fractionation in volcanic lake sediments (Azores-Portugal). Chemosphere 70, 1256-1263.

Rodrigues, A., Cunha, L., Amaral, A., Medeiros, J., Garcia, P., 2008. Bioavailability of heavy metals and their effects on the midgut cells of a phytopaghous insect inhabiting volcanic environments. Sci. Total Environ. 406, 116-122.

Ruiz, E., Rodriguez, L., Alonso-Azcarate, J., 2009. Effects of earthworms on metal uptake of heavy metals from polluted mine soils by different crop plants. Chemosphere 75, 1035-1041.

Siekierska, E., Urbanska-Jasik, D., 2002. Cadmium effect on the ovarian structure in earthworm Dendrobaena veneta (Rosa). Environ. Pollut. 120, 289-297.

Spurgeon, D., Tomlin, M., Hopkin, S., 1997. Influence of temperature on the toxicity of zinc to the earthworm Eisenia fetida. Bull. Environ. Contam. Toxicol. 58, 283-290.

Spurgeon, D., Stürzenbaum, S., Svendsen, C., Hankard, P., Morgan, A., Weeks, J., Kille, P., 2004. Toxicological, cellular and gene expression responses in earthworms exposed to copper and cadmium. Comp. Biochem. Physiol. Part C Toxicol. Pharmcol. 138, 11-21.
Spurgeon, D., Morgan, A., Kille, P., 2008. Current research in soil invertebrate ecotoxicogenomics. In: Hogstrand C, K.P. (Ed.), Comparative Toxicogenomics. Elsevier, Amsterdam 133-164.

Srivastava, R., Srivastava, S., Abidi, R., Das, M., 2009. Cellular level effects of meta toxicity on gills and liver of fishes. Comp. Biochem. Physiol., Part A: Mol. Integrative Physiol. 154, S19-S20.

Suthar, S., Singh, S., Dhawan, S., 2008. Earthworms as bioindicator of metals ( $\mathrm{Zn}, \mathrm{Fe}, \mathrm{Mn}, \mathrm{Cu}, \mathrm{Pb}$ and $\mathrm{Cd}$ ) in soils: is metal bioaccumulation affected by their ecological category? Ecol. Eng. 32 99-107.

Van Gestel C., Weeks J.. Recommendations of the Third International Workshop on earthworm ecotoxicology, Aarhus, Denmark, August 2001. Ecotoxicol. Environ. Saf. 2004; 57: 100-105.

Vega, M., Marigomez, J., Angulo, E., 1989. Quantitative alterations in the structure of the digestive cell of Littorina littorea on exposure to cadmium. Mar. Biol. 103, 547-553.

Vijver, M., Vink, J., Miermans, C., Van Gestel, C., 2003. Oral sealing using glue: a new method to distinguish between intestinal and dermal uptake of metals in earthworms. Soil Biol. Biochem. 35, 125-132.

Vijver, M., Wolterbeek, H., Vink, J., Van Gestel, C., 2005. Surface adsorption of metals onto the earthworm Lumbricus rubellus and the isopod Porcellio scaber is negligible compared to absorption in the body. Sci. Total Environ. 340, 271-280.

Viveiros, F., Ferreira, T., Cabral Vieira, J., Silva, C., Gaspar, J.L., 2008. Environmental influences on soil $\mathrm{CO}_{2}$ degassing at Furnas and Fogo volcanoes (São Miguel Island, Azores archipelago). J. Volcanol. Geotherm. Res. 177, 883-893.

Viveiros, F., Ferreira, T., Silva, C., Gaspar, J., 2009. Meteorological factors controlling soil gases and indoor $\mathrm{CO}_{2}$ concentration: a permanent risk in degassing areas. Sci. Total Environ. 407, 1362-1372.

Zaldibar, B., Cancio, I., Marigómez, I., 2007. Reversible alterations in epithelial cell turnover in digestive gland of winkles (Littorina littorea) exposed to cadmium and their implications for biomarker measurements. Aquat. Toxicol. 81, 183-196. 